\title{
DOI: http://dx.doi.org/10.33846/sfl1407
}

\section{Intervensi Dalam Pencegahan Cedera yang Tidak Disengaja pada Balita}

\section{Iin Suryatmana}

Program Studi Magister Keperawatan Komunitas, Fakultas Ilmu Keperawatan, Universitas Indonesia; iin.aqilazka19@gmail.com

Agus Setiawan

Departemen Keperawatan Komunitas, Fakultas Ilmu Keperawatan, Universitas Indonesia; a-setiawan@ui.ac.id (koresponden)

\section{ABSTRACT}

Unintentional injury in children is a global problem that often occurs in all countries in the world. Various prevention efforts need to be done by all relevant stakeholders to reduce the number of unintentional injuries in children. The purpose of this study was to identify the effect of interventions on the prevention of unintentional injuries on children under 5 years (toddlers). A literature study with descriptive analysis was used in this study. Articles were obtained through an online database search on the ScienceDirect, Wiley, Sage, ProQuest, Google scholar databases published from 2015 to 2020. This study identified 48 articles and 9 articles met the inclusion criteria. The results of the study identified that in general all articles $(n=7)$ showed a positive effect on injury prevention in children, 1 article did not clearly illustrate its effect on prevention of child injury, 1 article had no effect on prevention of child injury. Future studies need to consider various risk factors that influence the effectiveness of an intervention in order to get positive results.

Keywords: injury prevention; toddlers; unintentional child injury

\section{ABSTRAK}

Cedera yang tidak disengaja pada anak merupakan masalah global yang bayak terjadi di seluruh negara di dunia. Berbagai upaya pencegahan perlu dilakukan oleh semua stakeholder terkait untuk menekan angka kejadian cedera yang tidak disengaja pada anak. Tujuan studi ini adalah megidentifikasi pengaruh intervensi terhadap pencegahan cedera yang tidak disengaja pada anak di bawah 5 tahun (balita). Metode studi literatur dengan analisis deskriptif digunakan dalam studi ini. Artikel diperoleh melalui penelusuran online database ScienceDirect, Wiley, Sage, ProQuest, Google scholar yang terbit dari 2015 hingga 2020. Studi ini mengidentifikasi 48 artikel serta 9 artikel memenuhi kriteria inklusi. Hasil studi mengidentfikasi bahwa secara umum semua artikel $(n=7)$ menunjukkan dampak positif terhadap pencegahan cedera pada anak, 1 artikel tidak tergambar jelas pengaruhnya terhadap pencegahan cedera anak, 1 artikel tidak berpengaruh terhadap pencegahan cedera anak. Penelitian selanjutnya perlu mempertimbangakan berbagai faktor risiko yang mempengaruhi efektifitas suatu intervensi agar mendapatkan hasil yang positif.

Kata kunci: balita; cedera yang tidak disengaja pada anak; pencegahan cedera

\section{PENDAHULUAN}

Cedera merupakan pembunuh nomor 1 anak-anak dan remaja di Amerika Serikat. ${ }^{(1)}$ Cedera yang tidak disengaja menjadi penyebab utama morbiditas dan mortalitas anak-anak di Amerika Serikat. ${ }^{(2)}$ Penyebab utama cedera anak adalah kecelakaan kendaraan bermotor, ${ }^{(1)}$ kecelakaan lalu lintas, ${ }^{(3)}$ tenggelam, ${ }^{(1,4)}$ keracunan, ${ }^{(1)}$ luka bakar ${ }^{(1,5)}$ dan jatuh. ${ }^{(1,6)}$ Luka bakar merupakan urutan kelima paling umum cedera pada anak yang tidak fatal. ${ }^{(5)}$ Tenggelam menjadi penyebab utama ketiga kematian akibat kecelakaan atau cedera yang tidak disengaja di seluruh dunia (7\% dari semua kematian yang terkait cedera) serta anak-anak menjadi salah satu kelompok paling berisiko mengalami tenggelam. ${ }^{(4)}$ Selain itu statistik ${ }^{(4)}$ anak yang tenggelam dari sejumlah negara yang disajikan dalam Global Report on Drowning secara khusus mengungkapkan: tenggelam adalah salah satu dari 5 penyebab utama kematian orang berusia 1-14 tahun untuk 48 dari 85 negara dengan data yang memenuhi kriteria inklusi. ${ }^{(1)}$ Australia: tenggelam adalah penyebab utama kematian akibat cedera tidak disengaja pada anak usia 1-3 tahun. Bangladesh: tenggelam merupakan 43\% dari semua kematian pada anak-anak berusia 1-4 tahun. Cina: tenggelam adalah penyebab utama kematian akibat cedera pada anak usia 1-14 tahun. Amerika Serikat: tenggelam adalah penyebab utama kedua kematian akibat cedera yang tidak disengaja pada anak-anak berusia 1-14 tahun.(4) Sedangkan jatuh merupakan penyebab utama kedua kematian karena cedera yang tidak disengaja di seluruh dunia. ${ }^{(6)}$ Selain itu, kecelakaan/ cedera lalu lintas jalan merupakan penyebab utama kematian bagi anak-anak dan remaja berusia 5-29 tahun. ${ }^{(3)}$ Selain itu, data dari berbagai penelitian juga mengungkap berbagai risiko ataupun kejadian cedera yang tidak disengaja.

Penelitian di Kenya mengungkap bahwa anak laki-laki lebih mungkin mengalami cedera yang tidak disengaja daripada anak perempuan, terhitung 60,4\% dari mereka yang berusia di bawah 5 tahun $(\mathrm{n}=1359), 68,0 \%$ dari mereka yang berusia 5-9 tahun $(\mathrm{n}=1130)$, dan $73,0 \%$ dari mereka yang berusia $10-17$ tahun $(\mathrm{n}=1516){ }^{(7)}$ selanjutnya dijelaskan bahwa sebagian besar cedera terjadi di rumah $(79,9 \%)$ atau di jalan $(14,5 \%)$ untuk mereka yang berusia di bawah 5 tahun. ${ }^{(7)}$ Penelitian lain di India menyebutkan bahwa prevalensi cedera yang tidak disengaja lebih banyak pada anak lakilaki $(8,4 \%)$ daripada anak perempuan $(5,1 \%)$, kemudian jatuh secara tidak sengaja $(37,1 \%)$, gigitan anjing $(25 \%)$, dan cedera lalu lintas $(18,9 \%) .{ }^{(8)}$ Penelitian di Sri Lanka mengungkap faktor-faktor yang secara signifikan terkait dengan terjadinya cedera yang tidak disengaja di antara anak-anak yaitu pendapatan bulanan yang rendah dari keluarga $(\mathrm{p}=$ $0,045)$, dukungan sosial yang rendah kepada ibu dari anak indeks $(\mathrm{p}=0,022)$, dirawat oleh orang lain selain ibu pada 
siang hari $(\mathrm{p}=.002)$, sering terjadi pertengkaran di antara orang tua $(\mathrm{p}=.004)$, dan sering mengonsumsi alkohol ayah $(\mathrm{p}$ $=.001) \cdot{ }^{(9)}$ Penelitian di Swedia mengungkap 53\% peningkatan risiko cedera yang mengarah ke rawat inap pada remaja dengan kecacatan apapun dibandingkan dengan teman sebaya mereka yang tidak cacat. ${ }^{(10)}$ Meskipun demikian, cedera yang tidak disengaja pada anak dapat dicegah.

Pencegahan cedera pada anak telah banyak dilakukan. Berbagai kemajuan telah dibuat untuk pencegahan cedera pada anak. ${ }^{(1)}$ Hal ini terlihat dari angka kematian cedera anak yang telah menurun $29 \%$ dalam dekade terakhir. ${ }^{(1)}$ Namun demikian cedera masih menjadi penyebab utama kematian bagi anak-anak dan remaja. ${ }^{(1)}$ Tahun 2009, lebih dari 9.000 remaja usia 0-19 meninggal karena cedera yang tidak disengaja di Amerika Serikat. ${ }^{(1)}$ Di Bangladesh, Kolombia, Mesir dan Pakistan, $17 \%$ anak-anak dengan luka bakar memiliki cacat sementara dan $18 \%$ memiliki cacat permanen. ${ }^{(5)}$ Setiap tahun diperkirakan 646.000 orang meninggal akibat jatuh secara global, di mana lebih dari 80\% di negara berpenghasilan rendah dan menengah. ${ }^{(6)}$ Kemudian, diperkirakan 320.000 kematian tahunan akibat tenggelam di seluruh dunia. ${ }^{(4)}$

Berbagai strategi terus dilakukan untuk mencegah cedera tidak disengaja pada anak. Centers for Desease Control and Prevention (CDC) menyampaikan beberapa tindakan untuk pencegahan cedera pada anak dalam aksi nasional untuk pencegahan cedera pada anak seperti menumbuhkan kesadaran tentang masalah cedera anak dan dampaknya pada bangsa, sorot solusi pencegahan dengan menyatukan para pemangku kepentingan dengan serangkaian tujuan dan strategi bersama, memobilisasi upaya aksi nasional, terkoordinasi untuk mengurangi cedera anak. ${ }^{(1)}$

Tujuan dari studi ini adalah untuk mengetahui pengaruh intervensi untuk pencegahan cedera yang tidak disengaja pada anak balita.

\section{METODE}

Artikel ini ditulis dengan metode studi literatur. Literatur ditelusuri melalui online database ScienceDirect, Wiley, Sage, ProQuest, Google scholar. Artikel diambil dari terbitan tahun 2015 hingga 2020. Dengan kata kunci: "unintentional injury”, “unintentional child injury prevention”, "prevent unintentional childhood injury”. Sebanyak 48 artikel dipilih dan 9 artikel tersaring dengan kriteria inklusi: artikel merupakan terbitan Antara tahun 2015 hingga 2020, studi kuantitatif, studi kualitatif, studi longitudinal, laporan kasus, meneliti terkait pencegahan cedera yang tidak disengaja pada balita. Kriteria eksklusi studi ini yaitu studi literatur. Analisis dalam studi ini merupakan analisis deskriptif.

Artikel dikumpulkan malalui online database Emarald insight, PubMed, ScienceDirect, Wiley dan Google scholar.

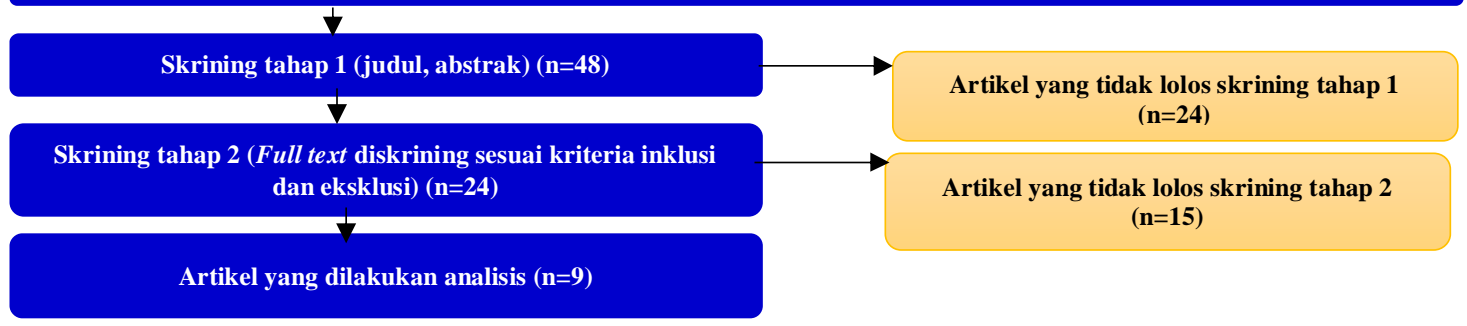

HASIL

Gambar 1. Diagram pengambilan data

Tabel 1. Dampak terhadap pencegahan cedera yang tidak disengaja pada anak

\begin{tabular}{|c|c|c|c|c|c|}
\hline \multirow{2}{*}{ Kode } & \multirow{2}{*}{ Tahun terbit } & \multirow{2}{*}{$\begin{array}{l}\text { Dampak positif terhadap pencegahan } \\
\text { cedera yang tidak disengaja pada anak }\end{array}$} & \multicolumn{3}{|c|}{ Jumlah $(\mathrm{n}=9)$} \\
\hline & & & Ya & Tidak & Tidak jelas \\
\hline N1 & 2018 & $\mathrm{Ya}$ & \multirow{9}{*}{7} & \multirow{9}{*}{1} & \multirow{9}{*}{1} \\
\hline N2 & 2018 & Ya & & & \\
\hline N3 & 2019 & Ya & & & \\
\hline N4 & 2016 & Tidak & & & \\
\hline N5 & 2019 & $\mathrm{Ya}$ & & & \\
\hline N6 & 2020 & $\mathrm{Ya}$ & & & \\
\hline N7 & 2016 & Ya & & & \\
\hline N8 & 2019 & Tidak jelas (perlu evaluasi lebih lanjut) & & & \\
\hline N9 & 2019 & Ya & & & \\
\hline
\end{tabular}

Studi ini menunjukkan hasil yang positif terhadap pencegahan cedera yang tidak disengaja pada anak ( $\mathrm{n}=7)$, hanya 1 artikel yang menyatakan tidak berdampak terhadap pencegahan cedera anak, sedangkan 1 artikel tidak tergambar jelas dampaknya terhadap pencegahan cedera anak. Artikel yang direview teracatat merupakan terbitan antara tahun 2016 hingga tahun 2020. Hasil ini lebih rinci dipaparkan dalam penjelasan dibawah ini.

Hasil studi ini mengidentifikasi beberapa program/ intervensi yang dilakukan terkait pencegahan cedera yang tidak disengaja pada balita. Wang et.al (2018) melakukan intervensi "promosi keselamatan" terhadap keluarga dengan pendapatan rendah yang memiliki balita. ${ }^{(1)}$ Penelitian ini mengungkap bahwa kelompok intervensi promosi keselamatan secara signifikan mengurangi masalah keselamatan dibandingkan kelompok kontrol selama 12 bulan follow-up. ${ }^{(1)}$ Lebih lanjut diungkapkan bahwa intervensi promosi keselamatan yang dibangun berdasarkan prinsip-prinsip social cognitive theory (SCT) memiliki potensi untuk mempromosikan lingkungan rumah yang aman untuk balita. ${ }^{(11)}$ Studi lain di Thailand melakukan penelitian terkait pencegahan cedera anak di rumah dengan suatu program workshop kolaboratif menggunakan 
pendekatan kualitatif untuk memahami pengalaman orang tua berpartisipasi dalam program "collaborative child home accidental injury prevention". ${ }^{(12)}$ Hasilnya peserta mengungkapkan bahwa keikutsertaan dalam workshop ini meningkatkan perilaku pencegahan cedera pada anak di rumah mereka. ${ }^{(12)}$

Studi lain dilakukan dengan melakukan edukasi terkait pencegahan cedera. Penelitian ini memberikan edukasi terkait pencegahan cedera pada anak terhadap 200 orang pengasuh anak di sebuah ruang tunggu klinik perawatan anak di Ohio. ${ }^{(13)}$ Pertisipan ini menyelesaikan 2 survei tindak lanjut, dan sebagian besar pengasuh (94\%) melaporkan mempelajari informasi baru tentang pencegahan cedera pada anak serta intervensi memberikan pengalaman ruang tunggu yang lebih baik (91\%). 93,5\% dari partisipan yang menyelesaikan survei tindak lanjut 2 minggu (84\%), membuat perubahan di rumah dan $42,7 \%$ membeli peralatan keselamatan baru. ${ }^{(13)}$

Sebuah studi kuasi-eksperimen di Swedia meneliti terkait kesadaran ibu terkait cedara pada anak serta pencegahannya. Hasil penelitian ini mengungkap bahwa ibu yang ikut dalam kelompok intervensi secara signifikan meningkatkan kesadaran mereka tentang fakta bahwa cedera anak terjadi di rumah dibandingkan dengan ibu dalam kelompok kontrol, namun tidak ada peningkatan kesadaran yang signifikan terhadap pencegahan cedera. ${ }^{(14)}$ Hal ini menyimpulkan bahwa intervensi yang diberikan memiliki efek positif pada kesadaran ibu terhadap fakta bahwa cedera anak terjadi di rumah, namun tidak meningkatkan kesadaran ibu terhadap pencegahan cedera anak. ${ }^{(14)}$

Peneliti di Palestina melakukan penelitian kualitatif terkait pencegahan cedera yang tidak disengaja pada anak berdasarkan perspektif ibu dari Palestina. Hasil studi yang dilakukan di Distrik Ramallah oleh Alrimawi et.al (2019) ini menyebutkan bahwa sebagian besar dari mereka memiliki sikap positif terhadap pencegahan cedera tidak disengaja pada anak di rumah. ${ }^{(15)}$ Namun demikian diungkapkan bahwa banyak faktor lingkungan memengaruhi praktik mereka, termasuk status ekonomi rendah, lingkungan fisik rumah, lingkungan sosial, dan lingkungan politik. ${ }^{(15)}$ Pengguanaan teknologi juga menjadi salah satu intrvensi yang dapat dilakukan terkait pencegahan cedera yang tidak disengaja pada anak. Sebuah prototype aplikasi telepon genggam yang diberi nama "Grow up Safely" (GUS) dirancang oleh Jones et.al (2020) untuk mengurangi cedera yang tidak disengaja pada anak dibawah lima tahun. ${ }^{(16)}$ Aplikasi ini dikembangkan untuk menyampaikan edukasi kesehatan terkait pencegahan cedera yang tidak disengaja yang sesuai dengan tahap perkembangan anak. ${ }^{(16)}$ Hasil studi ini mengungkap bahwa aplikasi ini dianggap ramah pengguna dan mudah dinavigasi, informatif, memberikan informasi baru, dan mereka akan mempertimbangkan untuk menggunakannya, saran yang diberikan masuk akal namun bahasanya terlalu rumit. ${ }^{(16)}$

Penelitian lain dilakukan oleh Morrongiello et.al (2016) dengan metode randomized controlled trial (RCT). Studi ini memberikan intervensi terkait Supervising for Home Safety (SHS) kepada pengasuh anak usia 2 hingga 5 tahun. Hasilnya menunjukkan bahwa dalam kelompok SHS terdapat peningkatan setelah intervensi seperti: keyakinan tentang kerentanan anak-anak terhadap cedera, kemampuan pencegahan cedera oleh pengasuh, dan efikasi diri untuk melakukannya; kesiapan untuk perubahan dalam pengawasan; dan pengawasan yang ketat. ${ }^{(17)}$ Studi lain meneliti apakah pengawasan ibu memoderasi hubungan faktor risiko anak, ibu, dan keluarga dengan cedera ringan anak-anak. ${ }^{(18)}$ Dalam studi ini ibu balita diwawancarai setiap dua minggu tentang cedera anak-anak mereka dan pengawasan mereka selama periode 6 bulan. Pengawasan memoderasi pengaruh kepuasan hubungan suami istri / pasangan terhadap frekuensi cedera anak. Temuan menunjukkan bahwa membantu ibu dengan tingkat kepuasan hubungan yang rendah memberikan pengawasan yang lebih dekat untuk anak-anak mereka dapat mengurangi efek kepuasan pernikahan yang rendah pada frekuensi cedera anak. ${ }^{(18)}$

Selain itu, penelitian lain meneliti terkait perilaku keselamatan anak dan cedera yang tidak disengaja yang dikaitkan dengan aturan keselamatan yang diajarkan orang tua mereka. Hasil analisis penelitian ini mengungkapkan aturan keselamatan yang diajarkan oleh ibu dan ayah kepada anak-anak mereka secara signifikan terkait dengan pengurangan risiko cedera tidak disengaja pada anak dan peningkatan yang sedang dalam hal perilaku keselamatan anak. ${ }^{(19)}$ Temuan ini menunjukkan bahwa orang tua yang mengajarkan aturan keselamatan kepada anak-anak bermanfaat untuk mengurangi risiko cedera yang tidak disengaja di antara anak-anak melalui peningkatan perilaku keselamatan anak. ${ }^{(19)}$

\section{PEMBAHASAN}

Salah satu studi di Thailand mengungkapkan bahwa keikutsertaan orang tua dalam workshop yang dilakukan peneliti meningkatkan perilaku pencegahan cedera pada anak di rumah mereka. ${ }^{(12)}$ Intervensi "promosi keselamatan" terhadap keluarga dengan pendapatan rendah yang memiliki balita oleh Wang et.al. mengungkap bahwa kelompok intervensi promosi keselamatan secara signifikan mengurangi masalah keselamatan serta memiliki potensi untuk mempromosikan lingkungan rumah yang aman untuk balita. ${ }^{(11)}$ Studi lain memberikan intervensi terkait Supervising for Home Safety (SHS) kepada pengasuh anak menunjukkan bahwa terdapat peningkatan setelah intervensi dalam beberapa hal seperti: keyakinan tentang kerentanan anak-anak, kemampuan pencegahan cedera oleh pengasuh, dan efikasi diri untuk melakukannya; kesiapan untuk perubahan dalam pengawasan. ${ }^{(17)}$ Sebuah studi di mana aturan keselamatan yang diajarkan oleh orang tua kepada anak-anak mereka secara signifikan terkait dengan pengurangan risiko cedera tidak disengaja dan peningkatan yang sedang dalam hal perilaku keselamatan anak. ${ }^{(19)}$ Hasil-hasil penelitian tersebut sejalan dengan strategi Centers for Desease Control and Prevention dalam meningkatkan edukasi dan training menyangkut pencegahan cedera pada anak, ${ }^{(1)}$ serta strategi pencegahan dari WHO dengan meningkatkan kesadaran akan keselamatan dan risiko cedera. ${ }^{(4-6)}$

Selain itu, penelitian yang memberikan edukasi terkait pencegahan cedera pada anak terhadap 200 orang pengasuh anak di sebuah ruang tunggu klinik perawatan anak di Ohio mengungkap bahwa partisipan yang menyelesaikan survei tindak lanjut 2 minggu (84\%), membuat perubahan di rumah dan $42,7 \%$ membeli peralatan keselamatan baru. ${ }^{(13)}$ Ini sejalan 
dengan dengan berbagai strategi intervensi yang efektif untuk anak-anak dari WHO seperti modifikasi peralatan / furnitur kamar anak, peralatan bermain, penggunaan pelindung jendela, penggunaan pagar / penghalang (sumur, pintu, kolam renang), kunjungan rumah, kampanye pendidikan publik, pendidikan untuk populasi rentan, pelatihan masyarakat. ${ }^{(4-6)}$

Pencegahan cedera anak dapat dilakukan dengan mempertimbangkan berbagai faktor risiko penghambat. Salah satu penelitian di Palestina terkait pencegahan cedera yang tidak disengaja pada anak berdasarkan perspektif ibu menunjukkan bahwa sebagian besar dari mereka memiliki sikap positif terhadap pencegahan cedera tidak disengaja pada anak di rumah. ${ }^{(15)}$ Namun demikian dipengaruhi berbagai faktor lingkungan, termasuk status ekonomi rendah, lingkungan fisik rumah, lingkungan sosial, dan lingkungan politik. ${ }^{(15)}$ Hal serupa diungkapkan oleh Tiruneh et.al (2017) dalam penelitiannya bahwa sumber pencahayaan di rumah, dan bahan lantai rumah juga merupakan faktor signifikan terhadap cidera yang tidak disengaja pada anak. ${ }^{(20)}$ Melihat hal ini, beberapa strategi yang sesuai menurut WHO dalam pencegahan cedera ini yaitu dengan melakukan intervensi seperti modifikasi peralatan rumah, serta pendidikan untuk populasi rentan. ${ }^{(6)}$

Secara garis besar temuan ini mengidentifikasi potensi dan dampak positif intervensi terhadap percegahan cedera yang tidak disengaja pada anak. Hanya 1 penelitian yang mengungkap bahwa intervensi yang dilakukan memberikan dampak positif terhadap kesadaran ibu akan fakta bahwa cedera anak terjadi di rumah namun ini tidak berdampak pada peningkatan kesadaran ibu. ${ }^{(14)} \mathrm{Hal}$ ini memberikan evaluasi dan potensi pengembangan intervensi yang lebih efektif pada penelitian yang akan datang dengan mempertimbangakan berbagai faktor risiko yang mempengaruhi.

\section{KESIMPULAN}

Studi ini mengungkap bahwa berbagai strategi intervensi secara garis besar berdampak positif terhadap pencegahan cedera yang tidak disengaja pada anak. Namun demikian, penelitian selanjutnya perlu mempertimbangakan berbagai faktor risiko yang mempengaruhi efektifitas suatu intervensi agar mendapatkan hasil yang positif.

\section{DAFTAR PUSTAKA}

1. CDC. National Action Plan for Child Injury Prevention. Centers for Desease Control and Prevention. 2019.

2. Borse NN, Gilchrist J, Dellinger AM, Rudd RA, Ballestreros MF, Sleet DA. CDC Childood Injury Report: Patterns of Un intentional Injuries among 0-19 Year Olds in the United States, 2000-2006. Atalanta; 2008.

3. WHO. Road traffic injuries [Internet]. 2020. Available from: https://www.who.int/en/news-room/fact-sheets/detail/roadtraffic-injuries

4. WHO. Drowning [nternet]. 2020. Available from: https://www.who.int/en/news-room/fact-sheets/detail/drowning

5. WHO. Burns [Internet]. 2020. Available from: https://www.who.int/en/news-room/fact-sheets/detail/burns

6. WHO. Falls [Internet]. 2018. Available from: https://www.who.int/en/news-room/fact-sheets/detail/falls

7. He H, Hung YW, Botchey IM, Bachani AM, Saidi H, Hyder AA, et al. Epidemiological Patterns Based On Hospital Reproduced with permission of copyright owner . Further reproduction prohibited without permission . 2016;22(Sup.2).

8. Parmeswaran GG, Kalaivani M, Gupta SK, Goswami AK. Unintentional Childhood Injuries in Urban Delhi: A Community-Based Study. 2017;5-7.

9. Punyadasa D, Samarakkody D. Community-Based Study on Family-Related Contributory Factors for Childhood Unintentional Injuries in an Urban Setting of Sri Lanka. 2016;

10. Jernbro C, Bonander C, Beckman L. The association between disability and unintentional injuries among adolescents in a general education setting: Evidence from a Swedish population-based school survey. 2020;13.

11. Wang Y, Gielen AC, Magder LS, Hager ER, Black MM. A randomised safety promotion intervention trial among lowincome families with toddlers. 2018;(1):41-7.

12. Machin AI, Ngamsuoy RNA, Ba PP. Collaborative child home injury prevention in Thailand: An action research study. 2018;(September 2017):206-13.

13. Habermehl N, Diekroger E, Lazebnik R, Kim G. Injury Prevention Education in the Waiting Room of an Underserved Pediatric Primary Care Clinic. 2019;

14. Carlsson A, Dykes AK, Jansson A, Bramhagen AC. Mothers' awareness towards child injuries and injury prevention at home : an intervention study. 2016;1-6.

15. Alrimawi I, Watson MC, Hall C, Saifan AR. Preventing Unintentional Injuries to Children Under 5 in Their Homes: Palestinian Mothers ' Perspectives. 2019;

16. Jones F, Aldiss S, Whitehouse A, Dopson A, Gibson F, Shawe J, et al. Reducing unintentional injuries in under fives : Development and testing of a mobile phone app. 2020;(November 2019):203-12.

17. Morrongiello BA, Hou S, Bell M, Walton K, Filion AJ, Haines J. Supervising for Home Safety Program: A Randomized Controlled Trial ( RCT ) Testing Community-Based Group Delivery. 2016;(October).

18. Damashek A, Borduin C. The Moderating Role of Maternal Supervision in the Relation of Social - Ecological Risk Factors to Children's Minor Injuries. J Clin Psychol Med Settings. 2019;(0123456789).

19. Zhou H, Fan L, Wu C, Luo A, Mo C, He G. Understanding the associations among parents teaching safety rules to children, safety behaviors and unintentional injuries in Chinese preschool children. 2019;118(October 2018):98-103.

20. Tadesse B, Boru B, Zelalem D, Seyume Y, Tesfaye E, Assefa B. African Journal of Emergency Medicine Factors associated with unintentional injury among the paediatric age population in the hospitals of Amhara National Regional State , Ethiopia. 2017;7:55-9. 